\title{
Development of Smartphone Apps for Skin Cancer Risk Assessment: Progress and Promise
}

Tiago M de Carvalho ${ }^{1}$, PhD; Eline Noels ${ }^{1}$, MD; Marlies Wakkee ${ }^{1}, \mathrm{MD}, \mathrm{PhD}$; Andreea Udrea ${ }^{2}$, PhD; Tamar Nijsten ${ }^{1}$, $\mathrm{MD}, \mathrm{PhD}$

\footnotetext{
${ }^{1}$ Department of Dermatology, Erasmus Medical Center, Rotterdam, Netherlands

${ }^{2}$ Department of Automatic Control and System Engineering, Polytechnic University of Bucharest, Bucharest, Romania
}

\section{Corresponding Author:}

Tiago M de Carvalho, $\mathrm{PhD}$

Department of Dermatology

Erasmus Medical Center

Doctor Molewaterplein 40

Rotterdam, 3015 GD

Netherlands

Phone: 31649331937

Email: t.decarvalho@erasmusmc.nl

\begin{abstract}
Skin cancer is a growing public health problem. Early and accurate detection is important, since prognosis and cost of treatment are highly dependent on cancer stage at detection. However, access to specialized health care professionals is not always straightforward, and population screening programs are unlikely to become implemented. Furthermore, there is a wide margin for improving the efficiency of skin cancer diagnostics. Specifically, the diagnostic accuracy of general practitioners and family physicians in differentiating benign and malignant skin tumors is relatively low. Both access to care and diagnostic accuracy fuel interest in developing smartphone apps equipped with algorithms for image analyses of suspicious lesions to detect skin cancer. Based on a recent review, seven smartphone apps claim to perform image analysis for skin cancer detection, but as of October 2018, only three seemed to be active. These apps have been criticized in the past due to their lack of diagnostic accuracy. Here, we review the development of the SkinVision smartphone app, which has more than 900,000 users worldwide. The latest version of the SkinVision app (October 2018) has a 95\% sensitivity (78\% specificity) for detection of skin cancer. The current accuracy of the algorithm may warrant the use of this app as an aid by lay users or general practitioners. Nonetheless, for mobile health apps to become broadly accepted, further research is needed on their health impact on the health system and the user population. Ultimately, mobile health apps could become a powerful tool to reduce health care costs related to skin cancer management and minimize the morbidity of skin cancer in the population.
\end{abstract}

(JMIR Dermatol 2019;2(1):e13376) doi: 10.2196/13376

\section{KEYWORDS}

skin cancer; early detection; mhealth; smartphone app; mobile phone

\section{Rationale for Using Mobile Health Apps for Early Detection of Skin Cancer}

There are three main types of skin cancers-malignant melanoma (MM), squamous cell carcinoma (SCC), and basal cell carcinoma (BCC) — with the latter two also known as keratinocyte carcinoma (KC). In the United States, it was estimated that about 91,000 people will be diagnosed with melanoma and 9300 will die due to MM in 2018 [1]; in addition, in 2012, more than 5 million people were diagnosed and 3 million received treatment for $\mathrm{KC}$, which is more than the values for all other cancers combined [2]. Globally, in 2015, there were about 351,000 new incident melanoma cases and 60,000 melanoma-related deaths [3], with the highest burden of disease in Australasia, North America, and Europe. In the last 30 years, the incidence of MM, adjusted for changes in the age distribution of the population, more than doubled in the United States (among Caucasians) and the United Kingdom; nearly doubled in Norway, Sweden, and New Zealand; and increased by approximately $75 \%$ in Australia [4]. This is mostly due to changes in risk factors such as increased exposure to ultraviolet light and indoor tanning [4-6]. Since these risk factors are mostly preventable, comprehensive prevention programs aimed at better 
sun protection behavior have been implemented in several countries, such as SunSmart in Australia [7].

Although several organizations have issued recommendations on how often to check skin lesions for individuals at higher risk (eg, Fitzpatrick scale I-III, a family history of melanoma, a history of sun-damaged skin, and multiple atypical nevi), ranging from every 3 months to every year [8], most countries do not have an organized early detection program for skin cancer. The US Preventive Services Task Force has issued an I-recommendation for skin cancer screening [9], indicating that there is insufficient evidence to evaluate the harms and benefits of skin cancer screening. Currently, there are only two major skin screening programs: (1) In the United States, the American Academy of Dermatology, which started in 1985, includes screening and skin cancer awareness education [10] and (2) in Germany, a national screening program was started in 2008 [11]; the program in Germany does not seem to be effective in reducing skin cancer-related mortality and morbidity [12].

In practice, it is difficult to provide a high-quality skin checks, even for high-risk individuals. Waiting times and, in some areas, dermatologist shortages, out-of-pocket costs, and distance to the nearest dermatologist [13] may discourage people at risk from receiving dermatological care. For example, in the United States, a study found that availability of a dermatologist within the county is associated with a $35 \%$ decrease in melanoma mortality [14]. Another US estimate found that only a quarter of individuals at higher risk of skin cancer have ever received a total skin body examination [8].

In several countries, namely, in the United Kingdom and the Netherlands, skin checks are first carried out by a general practitioner (GP, also sometimes referred to as primary care provider), who may then choose to refer a patient to a dermatologist if there is a suspicion of skin cancer. However, several studies suggest that the accuracy of GPs to detect skin cancer is relatively low [15-20]. The sensitivity of GPs without specific training to detect skin cancer was estimated to be below $60 \%$ in British and Dutch studies $[15,16]$. One US study found that only $35 \%$ of patients had a correct diagnosis [17]. Altogether, this may result in a delay in diagnosis or missing the cancer in its earlier stages when patient survival is more favorable and treatment is less costly. Furthermore, many GP consultations and subsequent referrals to a specialist to examine the skin for cancer result in a benign diagnosis. A Dutch study found that $69 \%$ of GP consultations related to suspicious skin lesions result in a benign diagnosis [19], and two separate studies in the Netherlands estimated that a large proportion (40\%) of referral cases to the dermatologist due to suspicion of skin cancer turned out to be benign cases [19,20]. Two studies (in the United States and Germany) including more than 70 dermatologists found that dermatologists' disease classification decisions have a specificity of $60 \%-80 \%$ [21,22], which may result in unnecessary biopsies/excisions.

Early detection and surveillance of skin cancer could be more efficient with mobile health (mHealth) apps, which are easily accessible due to the ubiquity of smartphone usage. One example of a smartphone app for self-assessment of skin lesions for skin cancer is the SkinVision app (SVA), developed by SkinVision, BV, The Netherlands). In the next section, we review the development of SkinVision app over time.

\section{Development of a Smartphone App for Skin Cancer Detection}

SkinVision is a smartphone app built as a digital dermatology service for self-monitoring skin lesions. It was launched in 2011 and as of October 2018, it was on its fifth major version. The workflow of the app is given in Figure 1.

Figure 1. Workflow of the SkinVision app service. SVA: SkinVision app.
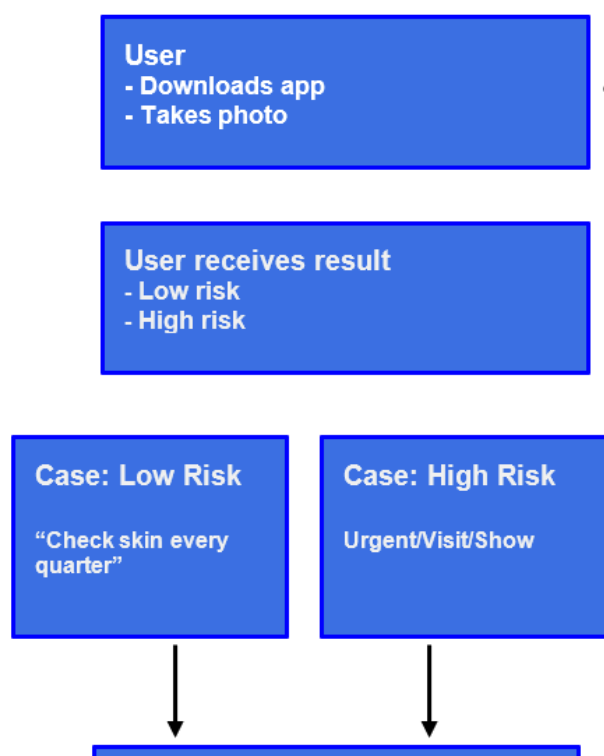

Follow-Up

- High risk: reminder message from SVA.

- Result of doctor visit

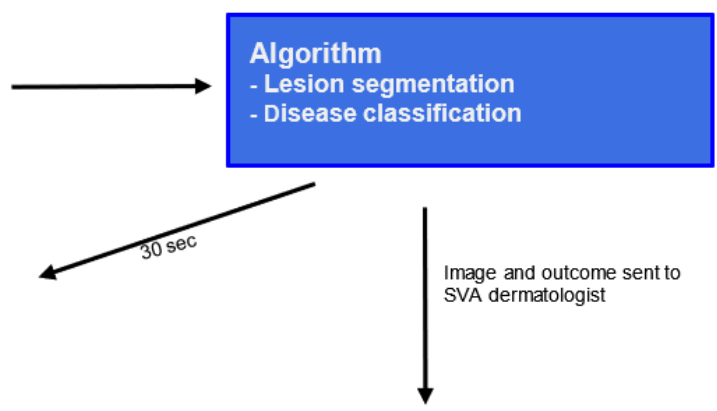

Image and outcome sent

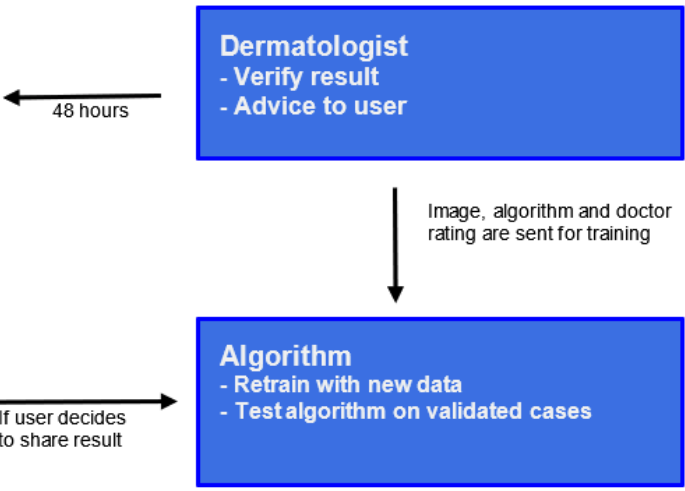


A user can self-assess the risk of a skin lesion for skin cancer by taking a photo with his/her smartphone, which is processed by an algorithm. The outcome of the procedure is a binary risk rating, which can be low or high. This smartphone app does not provide a diagnosis (eg, "you have melanoma"). For high-risk cases, the user receives advice from the costumer care team based on the image assessment of an in-house dermatologist.

\section{Development of the SkinVision App Service}

The history of the SkinVision app service is shown in Table 1. It went through several upgrades throughout its history, modifying the camera, the algorithm and its evaluation, type of lesions analyzed, and communication of the algorithm result to its user. One of the major initial challenges was related to image acquisition. In the beginning, there was no filter on the images sent for analyses, which meant that a significant proportion of the pictures taken by users was of insufficient quality to be analyzed by the disease classification algorithm or did not even contain a lesion to be analyzed. Since version 3 of the SkinVision app (2014), a special camera module [23] has been embedded, which only lets the camera take a photo after certain minimal quality conditions are met. Compared to unfiltered images taken with a standard smartphone camera, the camera module reduces the number of blurry photos by about $52 \%$ on an average (determined using 2018 data). Altogether, improvements in the camera module (namely, image quality checks) and the algorithm pipeline led to a reduction in the number of assessments that failed to produce a risk rating, from $26 \%$ in 2016 to $2 \%$ in 2018 on an average.

An overview of studies on the diagnostic accuracy of the SkinVision app is shown in Table 2. Diagnostic accuracy is evaluated based on two measures: sensitivity (proportion of lesions correctly classified as high risk) and specificity (the proportion of lesions correctly rated as benign). The first algorithm for skin lesion assessment was a rule-based fractal algorithm [24]. Initially, it was focused on pigmented skin lesions and only able to analyze whether MM was present in the lesion, and it was tested based on clinical review of images. The Munich University Hospital study was the first peer-reviewed publication where the SkinVision app algorithm was evaluated against histopathology [24], and thereafter, the algorithm achieved $73 \%$ sensitivity (83\% specificity). During the Catharina Hospital Eindhoven study [25], the algorithm was recalibrated to analyze pigmented and nonpigmented lesions. Currently, it can detect several types of skin cancer (MM, SCC, and BCC) and skin conditions that can lead to skin cancer, namely, actinic keratosis and Bowen disease. It achieved $80 \%$ sensitivity (78\% specificity) after inclusion of user clinical information. Although in the Eindhoven study, only 233 lesions were used for calibration, in 2018, the SkinVision app assembled a training dataset of more than 130,000 images that were risk classified by a dermatologist from the app's user database. This led to replacement of the rule-based classification algorithm by a machine learning approach (A Udrea et al, $\mathrm{PhD}$, unpublished material, 2019).

Table 1. Development of the SkinVision smartphone app.

\begin{tabular}{|c|c|c|c|c|c|c|}
\hline Version & Launch date & Algorithm & Camera & Type of skin lesion & $\begin{array}{l}\text { Type of skin cancer } \\
\text { detected }\end{array}$ & Testing \\
\hline 1 & May 2011 & $\begin{array}{l}\text { Rule-based fractal al- } \\
\text { gorithm version } 1\end{array}$ & $\begin{array}{l}\text { Standard smartphone } \\
\text { camera }\end{array}$ & $\begin{array}{l}\text { Pigmented skin lesion } \\
\text { only }\end{array}$ & Malignant melanoma & $\begin{array}{l}\text { Preclinical testing using } \\
600 \text { images against the } \\
\text { opinion of two dermatol- } \\
\text { ogists }\end{array}$ \\
\hline 2 & $\begin{array}{l}\text { December } \\
2012\end{array}$ & $\begin{array}{l}\text { Rule-based fractal al- } \\
\text { gorithm version } 2\end{array}$ & $\begin{array}{l}\text { Standard smartphone } \\
\text { camera, exclusion cri- } \\
\text { teria introduced }\end{array}$ & $\begin{array}{l}\text { Pigmented skin lesion } \\
\text { only }\end{array}$ & Malignant melanoma & $\begin{array}{l}\text { Preclinical testing using } \\
600 \text { images against the } \\
\text { opinion of two dermatol- } \\
\text { ogists }\end{array}$ \\
\hline 3 & $\begin{array}{l}\text { September } \\
2014\end{array}$ & $\begin{array}{l}\text { Rule-based fractal al- } \\
\text { gorithm version } 2\end{array}$ & $\begin{array}{l}\text { Camera module: exclu- } \\
\text { sion criteria automat- } \\
\text { ed }\end{array}$ & $\begin{array}{l}\text { Pigmented skin lesion } \\
\text { only }\end{array}$ & Malignant melanoma & $\begin{array}{l}\text { Clinical study, Munich } \\
\text { University Hospital }\end{array}$ \\
\hline 4 & July 2016 & $\begin{array}{l}\text { Rule-based fractal al- } \\
\text { gorithm version } 3 \text {, all } \\
\text { outcomes checked by } \\
\text { dermatologists (Sept } \\
\text { 2016) }\end{array}$ & $\begin{array}{l}\text { Camera module ver- } \\
\text { sion } 1\end{array}$ & $\begin{array}{l}\text { Pigmented and nonpig- } \\
\text { mented skin lesions }\end{array}$ & $\begin{array}{l}\text { Malignant melanoma, } \\
\text { squamous cell carcino- } \\
\text { ma, basal cell carcino- } \\
\text { ma, some premalig- } \\
\text { nant lesions }\end{array}$ & $\begin{array}{l}\text { Clinical study, Catharina } \\
\text { Hospital Eindhoven } \\
\text { (more types of skin can- } \\
\text { cer) }\end{array}$ \\
\hline 5 & $\begin{array}{l}\text { January } \\
2018\end{array}$ & $\begin{array}{l}\text { Machine learning algo- } \\
\text { rithm for image pro- } \\
\text { cessing and classifica- } \\
\text { tion }\end{array}$ & $\begin{array}{l}\text { Camera module major } \\
\text { version } 2^{\mathrm{a}}\end{array}$ & $\begin{array}{l}\text { Pigmented and nonpig- } \\
\text { mented skin lesions }\end{array}$ & $\begin{array}{l}\text { Malignant melanoma, } \\
\text { squamous cell carcino- } \\
\text { ma, basal cell carcino- } \\
\text { ma, some premalig- } \\
\text { nant lesions }\end{array}$ & $\begin{array}{l}\text { Data from previous clini- } \\
\text { cal studies and user } \\
\text { database with new algo- } \\
\text { rithm }\end{array}$ \\
\hline
\end{tabular}

\footnotetext{
${ }^{\mathrm{a}}$ New features include a dynamic grey threshold to differentiate between normal skin and lesion and a feature that prevents taking pictures without uniform luminosity.
} 
Table 2. Studies on the accuracy of the SkinVision app's risk assessment. All studies presented here were sponsored by the SkinVision app.

\begin{tabular}{|c|c|c|c|c|c|c|}
\hline Study & Data & Algorithm & Test set & Sensitivity (\%) & Specificity (\%) & Remarks \\
\hline $\begin{array}{l}\text { Maier et al, } \\
2014 \text { [24] }\end{array}$ & $\begin{array}{l}\text { University Hospital } \\
\text { Munich }\end{array}$ & $\begin{array}{l}\text { Rule-based fractal al- } \\
\text { gorithm version } 2\end{array}$ & $\begin{array}{l}26 \text { lesions with } \\
\text { melanoma }\end{array}$ & 73 & 83 & $\begin{array}{l}\text { Algorithm tested only } \\
\text { on malignant melanoma }\end{array}$ \\
\hline $\begin{array}{l}\text { Thissen et al, } \\
2017 \text { [25] }\end{array}$ & $\begin{array}{l}\text { Catharina Hospital } \\
\text { Eindhoven }\end{array}$ & $\begin{array}{l}\text { Rule-based fractal al- } \\
\text { gorithm version } 3\end{array}$ & $\begin{array}{l}108 \text { lesions including } \\
\text { several types of skin } \\
\text { cancer }\end{array}$ & $80^{\mathrm{a}}$ & $78^{\mathrm{a}}$ & $\begin{array}{l}\text { Algorithm tested mostly } \\
\text { on keratinocyte carcino- } \\
\text { ma (Munich data also } \\
\text { used for testing) }\end{array}$ \\
\hline $\begin{array}{l}\text { Udrea et al, } \\
2019^{b}\end{array}$ & $\begin{array}{l}\text { Clinical studies and } \\
\text { SkinVision app user } \\
\text { database }\end{array}$ & $\begin{array}{l}\text { Machine learn- } \\
\text { ing-based algorithm }\end{array}$ & $\begin{array}{l}285 \text { lesions with skin } \\
\text { cancer, from clinical } \\
\text { studies and a user } \\
\text { database with } \\
\text { histopathology infor- } \\
\text { mation }\end{array}$ & 95 & 78 & All types of skin cancer \\
\hline
\end{tabular}

\footnotetext{
${ }^{\mathrm{a}}$ After incorporating answers into a questionnaire about the skin lesion.

${ }^{b}$ Manuscript under peer review (June 2019). For more details on these results, see Multimedia Appendix 1.
}

\section{SkinVision App Service in 2018}

\section{Camera}

Before downloading the app, the smartphone should be equipped with a camera capable of producing a video stream with sufficiently high resolution. Although the app uses a regular smartphone camera, the camera module embedded in the app automatically places some restrictions to ensure minimal quality requirements of the images are met: The image needs to be focused, the lesion should be present and contained in the image, and there should be no hair or shadows covering the lesion. The module also prevents the camera from taking images that cannot be assessed by the algorithm (eg, lesions under a nail or near clothing in a skin fold).

\section{Algorithm for Lesion Assessment}

There are several steps to analyze the lesion. The first task of the algorithm is to identify and separate the lesion from normal skin. This is done using a machine learning technique called conditional Generative Adversarial Neural Network [26] (A Udrea et al, $\mathrm{PhD}$, unpublished material, 2019). After the lesion is segmented, all "noise" (eg, hair surrounding the lesion) is removed in the image by applying an inpainting procedure [27]. The third step is to extract the features from the lesion that are used in the disease classification algorithm. These features include 24 shape, color, and texture attributes that characterize the lesion. A Support Vector Machines (SVM) classifier is used to provide a risk rating, which can be high or low. The SVM model is obtained by maximizing sensitivity to detect cancer subject to a constraint of a minimal specificity value (eg, 80\%). The optimization is performed using a Particle Swarm Optimization algorithm [28]. The classification algorithm is regularly updated and retrained with new data. This is necessary to maintain robustness to variation due to imaging, newer devices, and the user population adopting the app.

\section{Training and Testing}

For training of the algorithm, we used images obtained from the user database (more than 130,000 pictures from 30,000 users), which received either a low- or high-risk tag during quality control of the algorithm by a dermatologist affiliated with SkinVision. A selection of cases clinically validated as low risk were randomly selected from the user database, while all cases rated as high risk or with a histopathological report were used, since there were considerably fewer of them. For testing the sensitivity, we used 285 skin lesions derived from both previous clinical studies (Munich and Catharina Hospital, 195 skin lesions, containing most common forms of skin cancer) and the user database ( 90 cases of melanoma that received histopathological confirmation from users). Furthermore, to test the specificity, we used 6000 randomly selected cases from the user database (June to August 2018), which were tagged as benign by SkinVision-affiliated dermatologists and were not used in training. An overview of these datasets together with the participant flowcharts are shown in Multimedia Appendix 1 .

\section{Performance Evaluation}

The gold standard (main comparator) to evaluate algorithm sensitivity is comparison against histopathologically validated cancers. The second comparator is the performance of the algorithm against the image assessment of the dermatologist (which is comparable to a teledermatology consult). In order to calculate the specificity, we use images of lesions that were classified by dermatologists as benign cases, since these are not usually biopsied, and therefore, there is no histopathology report. Sensitivity has improved from $73 \%$ in the first peer-reviewed study, where only MM was detectable, to $95 \%$ in the current version of the algorithm (78\% specificity), where the SkinVision app can detect all forms of skin cancer (Table 2 and Multimedia Appendix 1).

\section{Postassessment Follow-Up}

Since 2016, images processed by the algorithm are reviewed by at least one affiliated dermatologist. To help users with the interpretation of high-risk cases, a senior dermatologist adds advice depending on the probable severity of the disease. The advice can contain the labels "Show," "Visit," or "Urgent." "Show" indicates that the lesion should be shown at the next planned doctor appointment, "Visit" indicates that the appointment should be made soon, and "Urgent" advises the user to show the lesion to a doctor as soon as possible. Users 
with a low-risk rating only receive a reminder to check their skin regularly.

Assessments with a high-risk rating given by the dermatologist are followed up by the customer support department of the SkinVision app. If the user does not respond, he/she may receive additional messages encouraging a visit to the doctor, depending on the perceived severity of the disease. Some users share their diagnosis of skin cancer with the SkinVision app $(n=3806$, Multimedia Appendix 1). Of these, a small proportion $(338 / 3806,8.8 \%)$ share the histopathology report. At the end of September 2018, about 338 users had shared histopathological reports, of which 58\% (178/338) were of MM diagnosis. The histopathologically validated cases are used for training and testing the algorithm.

\section{Smartphone App Users}

In Table 3, we show self-reported demographic data on SkinVision app users. As of September 2018, the SkinVision app has performed more than 1.8 million assessments. Some of these users shared their demographic data with the SkinVision app: $56 \%(355,491 / 635,807)$ shared their age group and $28.5 \%$ $(181,706 / 635,807)$ shared their gender. Although skin cancer is more prevalent in older age groups, only $7 \%$ of the people were older than 60 years of age $(19,358 / 355,491)$ in the user database and about $31 \%(110,529 / 355,491)$ were younger than 30 years of age. More than $60 \%$ of the users were female $(118,182 / 181,706)$. A majority of the users come from the following countries: The Netherlands $(n=111,063,17.4 \%)$, United Kingdom $(\mathrm{n}=109,178,17.2 \%)$, Australia $(\mathrm{n}=109,126$, $17.2 \%)$, New Zealand ( $\mathrm{n}=70,244,11 \%)$, and Belgium $(\mathrm{n}=21,328$, $3.3 \%)$.

Table 3. Self-reported demographic characteristics of the SkinVision app users. The data are from the SkinVision app proprietary user database, accessed in September 2018. Numbers are based on users, who made a picture that was evaluated by the algorithm, and filled the online questionnaire.

\begin{tabular}{|c|c|}
\hline Characteristic & Users \\
\hline Number of registered users & 931,789 \\
\hline Total number of users with an assessment & $635,807^{\mathrm{a}}$ \\
\hline \multicolumn{2}{|l|}{ Gender $^{b}, \mathbf{n}(\%)$} \\
\hline Male & $62,914(9.9)$ \\
\hline Female & $118,182(18.6)$ \\
\hline Missing & $454,731(71.5)$ \\
\hline \multicolumn{2}{|l|}{ 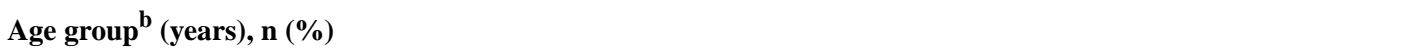 } \\
\hline$<30$ & $110,529(17.4)$ \\
\hline 30-39 & $98,327(15.5)$ \\
\hline $40-49$ & $74,928(11.8)$ \\
\hline $50-59$ & $46,840(7.4)$ \\
\hline $60-69$ & $19,358(3.0)$ \\
\hline$>70$ & $5509(0.9)$ \\
\hline Missing & $280,316(44.0)$ \\
\hline \multicolumn{2}{|l|}{ Country, n (\%) } \\
\hline The Netherlands & $111,063(17.4)$ \\
\hline Australia & $109,178(17.2)$ \\
\hline United Kingdom & $109,126(17.2)$ \\
\hline New Zealand & $70,244(11.0)$ \\
\hline Belgium & $21,128(3.3)$ \\
\hline Others & $215,355(33.9)$ \\
\hline
\end{tabular}

${ }^{\text {a }}$ Some users may be health care providers taking pictures of multiple patients, so this is likely an underestimate.

${ }^{b}$ For the gender and age categories, about $75 \%$ and $44 \%$, respectively, did not fill any data. 


\section{State of the Field}

\section{Available Mobile Health Apps for Skin Cancer Detection}

A recent review [29] found that there are 43 smartphone apps developed for skin cancer detection, monitoring, and education. Of these, nine smartphone apps use an algorithm for image analysis [29]. We verified the current status of these smartphone apps in December 2018 with Google search and PubMed and in app stores. The results are presented in Table 4 . We confirm that seven apps claim to use an algorithm for image analysis. Of these, four do not seem to be active as of October 2018. Compared to a previous review conducted in July 2014 [30], there are now less apps available for risk assessment of skin lesions through image analysis (three instead of four).

Table 4. List of smartphone apps that claim to perform skin lesion image analyses to detect skin cancer, based on a systematic review [29]. ${ }^{\mathrm{a}}$

\begin{tabular}{|c|c|c|c|c|}
\hline Commercial name & Algorithm $^{\mathrm{b}}$ & Evidence on PubMed & Status & Source $^{c}$ \\
\hline DermaCompare & Machine learning & Not found & $\begin{array}{l}\text { Removed from app store, last } \\
\text { update on January } 2017\end{array}$ & [31] \\
\hline Lubax & $\begin{array}{l}\text { Content-based image retrieval, } \\
\text { k-nearest neighbor }\end{array}$ & $\begin{array}{l}\text { Yes, one supported peer-re- } \\
\text { viewed publication }^{\mathrm{d}}\end{array}$ & $\begin{array}{l}\text { Removed from app store, last } \\
\text { update on February } 2015\end{array}$ & {$[32,33]$} \\
\hline MSkinDoctor $^{\mathrm{e}}$ & $\begin{array}{l}\text { Grab cut algorithm (segmenta- } \\
\text { tion) and } \operatorname{SVM}^{\mathrm{f}} \text { (classification) }\end{array}$ & $\begin{array}{l}\text { Not found; there is a conference } \\
\text { abstract only }\end{array}$ & $\begin{array}{l}\text { Removed from app store, up- } \\
\text { date on February } 2016\end{array}$ & [34] \\
\hline MySkinMap & Machine learning & Not found & $\begin{array}{l}\text { Removed from app store, last } \\
\text { update on September } 2016\end{array}$ & [35] \\
\hline SkinScan & $\begin{array}{l}\text { Image processing techniques, } \\
\text { ABCDE rule }\end{array}$ & Unclear $^{\mathrm{g}}$ & Available & {$[36]$} \\
\hline SkinVision & $\begin{array}{l}\text { Conditional generative adversar- } \\
\text { ial neural network (segmenta- } \\
\text { tion) and SVM (classification) }\end{array}$ & $\begin{array}{l}\text { Yes, two supported peer-re- } \\
\text { viewed publications, evaluated } \\
\text { in independent publications }\end{array}$ & Available & $\begin{array}{l}\text { [23-25,37], A Udrea et } \\
\text { al, PhD, unpublished } \\
\text { material, } 2019\end{array}$ \\
\hline SpotMole & $\begin{array}{l}\text { Image processing techniques, } \\
\text { ABCDE rule }\end{array}$ & $\begin{array}{l}\text { Yes, evaluated in independent } \\
\text { publications }\end{array}$ & Available $^{\mathrm{h}}$ & {$[38]$} \\
\hline
\end{tabular}

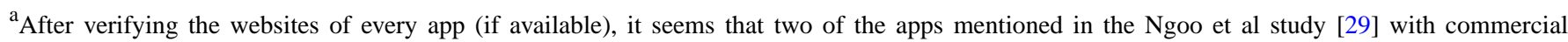
names-Myskinpal and Skin Prevention - Photo Body—do not claim to perform automated image analysis for risk assessment. They only store images of moles to track changes.

${ }^{\mathrm{b}}$ If available, the information is retrieved from scientific publications; otherwise, it is collected from the company's own website or app store description.

${ }^{\mathrm{c}}$ Accessed on Dec 12, 2018.

${ }^{\mathrm{d}}$ Results obtained in this publication [32] only for melanomas and large lesions.

${ }^{\mathrm{e}}$ There is another app available with the same name; however, that one does not perform image analyses.

${ }_{\text {f }}$ VM: support vector machines.

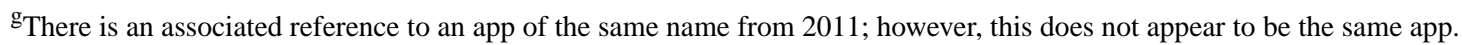

${ }^{\mathrm{h}}$ This smartphone app has a website (spotmole.com); however, it was offline at the last time of access (Dec 12, 2018). It is unclear if this project is still alive, given the fact that the last update was in March 2016 and that it seems this app is being developed by a single individual.
}

\section{Comparison of the SkinVision App With Other Apps}

Currently, there seem to be three apps available for detection of skin cancer, including SkinVision app, SpotMole, and skinScan. All three allow the user to take a picture with the smartphone camera. The SkinVision app algorithm is based on machine learning techniques, while SpotMole and skinScan use algorithms inspired by the ABCDE rule [39]. The SkinVision app involves quality control by a dermatologist; however, the other apps do not seem to offer any further follow-up or advice to users.

Tables 2 and 5 show the diagnostic accuracy results from recent publications. We found five peer-reviewed studies and one submitted study about two available mHealth apps and two mHealth apps that do not exist anymore. Of the three currently available apps, no diagnostic accuracy or other studies were found for skinScan. The other two smartphone apps were evaluated in at least one study [40], and only one app (ie,
SkinVision app) [24,25] has published evidence to show whether their proprietary algorithm is accurate.

mHealth apps for skin cancer assessment (including SkinVision app) have been criticized in past studies [40,41], because their accuracy was found to be significantly lower than that of a dermatologist. In Tables 2 and 5, only three studies showed a diagnostic accuracy close to that of a dermatologist, and one of these studies [32] only showed a high accuracy for large melanoma lesions. Although some of these studies are recent, these findings are possibly already outdated, as this is a rapidly evolving field. These results could also be explained by the limited sample size, including too few skin cancer cases and selected samples, which may be inadequate to calculate sensitivity or specificity or, in the case of SkinVision app, nonutilization of the full service with the dermatologists' advice.

Overall, the amount of evidence on the diagnostic accuracy of smartphone apps is still scarce, as there are few mHealth apps 
providing this service. It is also difficult to make an accurate comparison between different apps, since the rate of service or algorithm change is faster than the process of peer-review publication. It could also be the case that some developers may choose to publish their results in sources that are not referenced in PubMed, namely, ArXiv. An illustrative example of these difficulties is a Cochrane review [42] published in December 2018 on the diagnostic accuracy of smartphone apps, which only found two studies but only included articles published before August 2016, making it possibly obsolete at the time of publication. For these reasons, one should be cautious when interpreting the available literature.

Table 5. Recent studies on the diagnostic accuracy of smartphone apps for risk assessment of skin lesions.

\begin{tabular}{|c|c|c|c|c|c|c|}
\hline App, study, year & $\begin{array}{l}\text { Location for data } \\
\text { collection }\end{array}$ & Algorithm & Test Set & $\begin{array}{l}\text { Sensitivity }(95 \% \\
\mathrm{CI})\end{array}$ & $\begin{array}{l}\text { Specificity }(95 \% \\
\text { CI) }\end{array}$ & Remarks \\
\hline $\begin{array}{l}\text { SkinVision app, } \\
\text { Ngoo et al, } 2018 \\
{[40]}\end{array}$ & $\begin{array}{l}\text { Princess Alexandra } \\
\text { Hospital, Brisbane }\end{array}$ & $\begin{array}{l}\text { Rule-based fractal } \\
\text { algorithm version } 2\end{array}$ & $\begin{array}{l}1 \text { malignant } \\
\text { melanoma, } 41 \text { clini- } \\
\text { cally suspicious le- } \\
\text { sions }^{\mathrm{a}}\end{array}$ & $\begin{array}{l}\text { iOS: } 57 \%(41- \\
73), \text { Android: } \\
72 \%(58-87)^{b}\end{array}$ & $\begin{array}{l}\text { iOS: } 50 \%(22- \\
78), \text { Android: } \\
27 \%(1-56)^{\mathrm{b}}\end{array}$ & $\begin{array}{l}\text { Only } 1 \text { malignant } \\
\text { melanoma was } \\
\text { found }\end{array}$ \\
\hline $\begin{array}{l}\text { SpotMole, Ngoo et } \\
\text { al, } 2018 \text { [40] }\end{array}$ & $\begin{array}{l}\text { Princess Alexandra } \\
\text { Hospital, Brisbane }\end{array}$ & $\begin{array}{l}\text { Algorithm based on } \\
\text { the ABCDE rule }\end{array}$ & $\begin{array}{l}1 \text { malignant } \\
\text { melanoma, } 41 \text { clini- } \\
\text { cally suspicious le- } \\
\text { sions }^{\mathrm{a}}\end{array}$ & $43 \%(28-58)$ & $80 \%(60-100)$ & $\begin{array}{l}\text { Only } 1 \text { malignant } \\
\text { melanoma was } \\
\text { found }\end{array}$ \\
\hline $\begin{array}{l}\text { Dr Mole, Ngoo et } \\
\text { al, } 2018[40]\end{array}$ & $\begin{array}{l}\text { Princess Alexandra } \\
\text { Hospital, Brisbane }\end{array}$ & $\begin{array}{l}\text { Algorithm based on } \\
\text { the ABCDE rule }\end{array}$ & $\begin{array}{l}1 \text { malignant } \\
\text { melanoma, } 41 \text { clini- } \\
\text { cally suspicious le- } \\
\text { sions }^{\mathrm{a}}\end{array}$ & $21 \%(9-34)$ & $100 \%(100-100)$ & $\begin{array}{l}\text { Only } 1 \text { malignant } \\
\text { melanoma was } \\
\text { found }\end{array}$ \\
\hline $\begin{array}{l}\text { Lubax, Cheng et } \\
\text { al, 2015 [32] }\end{array}$ & $\begin{array}{l}\text { DermNetNZ, New } \\
\text { Zealand, and Los } \\
\text { Angeles }^{c}\end{array}$ & $\begin{array}{l}\text { Content-based im- } \\
\text { age retrieval }\end{array}$ & $\begin{array}{l}208 \text { lesions with } \\
\text { melanoma }^{d}\end{array}$ & $90 \%(86-94)$ & $92 \%(85-95)$ & $\begin{array}{l}\text { Algorithm tested on- } \\
\text { ly on malignant } \\
\text { melanoma (large le- } \\
\text { sions only) }\end{array}$ \\
\hline $\begin{array}{l}\text { Not reported, Do- } \\
\text { rairaj et al, } 2017 \\
{[41]^{\mathrm{e}}}\end{array}$ & $\begin{array}{l}\text { Galway University } \\
\text { Hospital }\end{array}$ & Not reported & $\begin{array}{l}9 \text { malignant } \\
\text { melanomas }\end{array}$ & $80 \%(52-96)$ & $9 \%(0-41)$ & $\begin{array}{l}\text { Algorithm tested on- } \\
\text { ly on malignant } \\
\text { melanoma }\end{array}$ \\
\hline
\end{tabular}

${ }^{a}$ All lesions had a benign final histopathology diagnosis with the exception of one melanoma in situ.

${ }^{b} \mathrm{Ngoo}$ et al 2017 [40] reported the results per type of operating system: iOS/Android.

${ }^{\mathrm{c}}$ DermNetZN is a publicly accessible skin lesion image database from New Zealand containing about 20,000 images. Images collected within the Los Angeles county were collected by the app company. No reference to a clinical site of the data collection was given in the publication.

dAlgorithm was only tested on "large lesions" defined as melanomas with a diameter $\geq 10 \mathrm{~mm}$.

eDespite the study being published in 2017, the study took place in 2012.

\section{Improving the Diagnostic Accuracy of Mobile Health Apps}

A promising avenue to improve the diagnostic accuracy of mHealth apps is to train machine learning algorithms on large databases of skin cancer images. Several algorithms for skin cancer classification were recently developed based on clinical or dermoscopic images, with algorithm accuracy routinely on par with a dermatologist $[21,22,43]$. For mHealth apps, the task of skin lesion classification is more difficult, as the images are taken by the users themselves, with variability in angle, luminosity, and smartphone model. The SkinVision app showed that skin lesion classification based on smartphone images can also achieve high accuracy (Table 2; A Udrea et al, PhD, unpublished material, 2019).

\section{Alternatives to Mobile Health Apps}

Early detection of skin cancer could be significantly improved by launching a population screening program, but this is unlikely to become common due to the high costs and lack of evidence on harms and benefits $[9,44]$. As the main risk factors for skin cancer like indoor tanning or ultraviolet exposure are, in large part, preventable [45], primary prevention and awareness campaigns (eg, Melanoma Monday and SunSmart in Australia) could have a better cost-benefit ratio than early detection [46]. These campaigns are a way for the general public to proactively adopt preventive behaviors and possibly learn how to recognize suspicious skin lesions [7]; they seemed to have resulted in better sun protection behavior [47]. On the other hand, this success can be reversed if these awareness efforts are not continuous [47] and they do not solve the shortages or difficulties in access to high-quality skin checks.

Training GPs or nurses with a special interest in recognizing skin cancer increases the capacity for early and accurate detection. However, compared to mHealth apps, it still requires face-to-face contact, and it is likely not enough to address all needs $[13,48]$. Store-and-forward teledermatology [49] allows users to take a photo and have it analyzed remotely by a dermatologist. This may solve some of the problems with access to care, but is solely based on a clinical assessment of a health care professional and is thus not automated. Smartphone apps with good performance are likely to be more efficient and could 
lead to larger cost savings for the health system compared to the above mentioned alternatives.

\section{Usability Risks of Smartphone Apps}

Smartphone apps pose some risks for the user, specifically, if the algorithm returns a negative result while the user has cancer, and detection and treatment of skin cancer are delayed. It is very challenging to study the rate of false-negatives due to a lack of histological verification. The user may also fail to assess all relevant skin lesions, in particular, if they are located in places that are hard to reach or that the user cannot see. Given that the specificity of SkinVision app is about $80 \%$, there will be a few false-positive cases. This may cause unnecessary stress on users or unnecessary visits to the GP/dermatologist. Finally, the user may not follow the advice given in the smartphone app due to a lack of trust or unawareness.

\section{Evaluating the Health Impact of Mobile Health Apps}

\section{Impact of Mobile Health Apps on Health Care Costs}

A Dutch study based on national claims data observed an increase of about $67 \%$ in skin cancer-related costs between 2007 and 2017 (E. Noels, MD, unpublished data, 2019). This is due to higher costs of skin cancer treatments, for example, newly available expensive targeted immunotherapies for late-stage melanomas and, to a lesser extent, due to an increase in the skin cancer incidence. mHealth apps for self-assessment of skin lesions could limit this cost increase by (1) by detecting cancers early, which will reduce the average cost of treatment (ie, less advanced disease) and recovery and (2) reducing the need for doctor visits, since many primary care (GP)-related consultations either result in a benign diagnosis or in referrals to a specialist of cases that are later diagnosed as benign [19].

\section{Impact of Mobile Health Apps on Public Health}

Easy access to a high-quality assessment of skin lesions may lead to detection of skin cancers at an earlier stage, when their prognosis and treatment are more favorable. On the other hand, this could also cause overdiagnosis and overtreatment. Currently, evidence on the benefits and harms of skin cancer screening is insufficient $[9,44]$. To date, there are no randomized skin cancer screening trials, and it is unlikely that there will be new trials launched in the near future, since they would require a substantial number of patients and a long follow-up and it would be difficult and possibly unethical to guarantee that people in the control group would not access skin cancer detection methods. Consequently, it is difficult to determine whether early detection of skin cancer reduces skin cancer specific mortality. Another important target outcome could be the incidence of advanced melanoma. Therefore, indirect evidence on harms and benefits could be obtained by comparing the stage distribution of cancers detected early with a smartphone app from national registries.

\section{Implementation of Mobile Health Apps in the Health System}

The health impact of mHealth apps also depends on where it is implemented, that is, whether it is restricted to health care professionals such as GPs or dermatologists or accessible to the lay population. Offering apps directly to lay users could result in significantly greater efficiency gains for the health system; however, some regulatory bodies may prefer to restrict the usage to health care professionals to minimize usability risks. The regulatory framework is evolving quickly, with the National Institute for Health and Care Excellence in the United Kingdom suggesting a comprehensive approach to regulate mHealth technologies, taking into account not only the safety and efficacy of the app, which can be shown by carrying out a diagnostic accuracy study, but also whether it can plausibly improve current health care pathways, acceptability with users, and cost-effectiveness compared to usual care [50].

\section{Barriers to Access of Mobile Health Apps}

After implementation, the health impact of mHealth apps will also depend on the persistence of barriers to adoption among users (either lay persons or care providers). Zhao et al [51] described a technology acceptance model for mobile health [51]. For lay users, age can play a role in the rate of adoption [51]. Middle-aged and older users (the ones who are at a higher risk of skin cancer) may give more importance to the perceived amount of effort needed to learn how to use the smartphone app and the perceived personal risk for skin cancer. For clinicians, we believe the perceived ease of use also plays an important role, since clinicians have a limited amount of time. Other important factors may include perceived usefulness and efficacy of the smartphone apps, namely, whether clinicians believe in the quality of the app and whether they believe it provides the necessary information to make a clinical decision.

\section{Postmarket Surveillance of Mobile Health Apps}

A key point for mHealth apps for skin cancer detection consists of performing appropriate market surveillance activities in order to minimize usability risks, since data based on clinical studies in a controlled setting are likely not sufficient to control for differences in image-taking behavior or characteristics of the smartphone model. Algorithms used in mHealth apps should then be updated periodically, given the feedback from its users, whether they are lay users or clinicians. It is not easy to have complete follow-up from users, since due to privacy reasons, it is not straightforward for the smartphone apps to obtain access to the final clinical or histopathological diagnosis after the lesion is assessed by the algorithm.

\section{Future Research}

Research is still needed to establish the societal value of mHealth apps. First, there remains a need for more high-quality studies on their diagnostic accuracy in different populations. Second, given that these smartphone apps are accurate enough to be used by laypersons and GPs, its health and cost effects are yet to be evaluated.

The impact on the health system in terms of cost reduction due to less skin lesion-related visits still needs to be tested, ideally 
with a randomized control trial (RCT) accompanied by a cost-effectiveness analysis. However, performing an RCT may prove difficult. To design a trial capable of detecting a difference in the number of doctor visits, the sample size needed to carry out such a study is in the thousands, as shown by the Dutch data from 2010 [52] suggesting that about 93 consultations for every 1000 patients are related to skin cancer. The main problem is that this type of RCT has a high risk of contamination in the control group (no smartphone app), since access to smartphone apps and their usage is relatively simple. An alternative solution could be to follow a quasi-experimental approach for the design of the study [53].

In the absence of large RCTs and long-term follow-up data, modelling could be used to estimate the harms and benefits of early detection of skin cancer. There are a few studies in the literature that modelled the incidence and mortality of skin cancer [54-56]. The main drawback of these modelling studies is the difficulty in estimating tumor onset and progression. This could be addressed by forming a coalition of multiple modelling groups for skin cancer, like the Cancer Intervention and Surveillance Modelling Network (CISNET) group has done for other cancer sites [57].

\section{Summary and Conclusions}

Given the difficulties in access to high-quality care for early detection of skin cancer, there is considerable interest in developing algorithms and apps for skin cancer lesion assessment. Although mHealth apps have been criticized in the past due to their poor accuracy, the SkinVision app has a high accuracy to evaluate the risk of skin lesions for skin cancer. This was achieved due to improvements in the processing of images taken with the smartphone camera and a large risk-labeled image database from users, which was used to train a machine learning algorithm.

However, there are still many open questions regarding the usage of mHealth apps. National health authorities need to decide where to position these apps in the health care system (lay population, GPs, or dermatologists). Health effects of early and more accurate detection are difficult to estimate. There is currently no high-quality evidence on the health and cost benefits and harms of early detection of skin cancer, namely, on the trade-off between doctor visits and lives saved/advanced cases avoided. The reduction of the skin cancer burden on the health system and in the population could be substantial, as earlier detection of skin cancer could result in a lower average cost of treatment and a reduction in the number of doctor visits. However, further studies are needed to confirm this.

\section{Conflicts of Interest}

AU is affiliated with SkinVision, MW is an occasional advisor for SkinVision, and TN has received an unrestricted research grant from SkinVision.

\section{Multimedia Appendix 1}

Datasets used to train and test the SkinVision algorithm.

[PDF File (Adobe PDF File), 432KB-Multimedia Appendix 1]

\section{References}

1. Siegel R, Miller KD, Jemal A. Cancer statistics, 2018. CA Cancer J Clin 2018 Dec;68(1):7-30 [FREE Full text] [doi: 10.3322/caac. 21442] [Medline: 29313949]

2. Rogers HW, Weinstock MA, Feldman SR, Coldiron BM. Incidence Estimate of Nonmelanoma Skin Cancer (Keratinocyte Carcinomas) in the U.S. Population, 2012. JAMA Dermatol 2015 Oct;151(10):1081-1086. [doi:

10.1001/jamadermatol.2015.1187] [Medline: 25928283]

3. Karimkhani C, Green AC, Nijsten T, Weinstock MA, Dellavalle RP, Naghavi M, et al. The global burden of melanoma: results from the Global Burden of Disease Study 2015. Br J Dermatol 2017 Jul 30;177(1):134-140 [FREE Full text] [doi: 10.1111/bjd.15510] [Medline: 28369739]

4. Whiteman DC, Green AC, Olsen CM. The Growing Burden of Invasive Melanoma: Projections of Incidence Rates and Numbers of New Cases in Six Susceptible Populations through 2031. J Invest Dermatol 2016 Jun;136(6):1161-1171 [FREE Full text] [doi: 10.1016/j.jid.2016.01.035] [Medline: 26902923]

5. Erdmann F, Lortet-Tieulent J, Schüz J, Zeeb H, Greinert R, Breitbart EW, et al. International trends in the incidence of malignant melanoma 1953-2008--are recent generations at higher or lower risk? Int J Cancer 2013 Jan 15;132(2):385-400 [FREE Full text] [doi: 10.1002/ijc.27616] [Medline: 22532371]

6. Apalla Z, Nashan D, Weller RB, Castellsagué X. Skin Cancer: Epidemiology, Disease Burden, Pathophysiology, Diagnosis, and Therapeutic Approaches. Dermatol Ther (Heidelb) 2017 Jan;7(Suppl 1):5-19 [FREE Full text] [doi:

10.1007/s13555-016-0165-y] [Medline: 28150105]

7. Iannacone MR, Green AC. Towards skin cancer prevention and early detection: evolution of skin cancer awareness campaigns in Australia. Melanoma Manag 2014 Aug;1(1):75-84 [FREE Full text] [doi: 10.2217/mmt.14.6] [Medline: 30190812] 
8. Johnson MM, Leachman SA, Aspinwall LG, Cranmer LD, Curiel-Lewandrowski C, Sondak VK, et al. Skin cancer screening: recommendations for data-driven screening guidelines and a review of the US Preventive Services Task Force controversy. Melanoma Manag 2017 Mar;4(1):13-37 [FREE Full text] [doi: 10.2217/mmt-2016-0022] [Medline: 28758010]

9. US Preventive Services Task Force, Bibbins-Domingo K, Grossman DC, Curry SJ, Davidson KW, Ebell M, et al. Screening for Skin Cancer: US Preventive Services Task Force Recommendation Statement. JAMA 2016 Jul 26;316(4):429-435. [doi: 10.1001/jama.2016.8465] [Medline: 27458948]

10. Okhovat J, Beaulieu D, Tsao H, Halpern AC, Michaud DS, Shaykevich S, et al. The first 30 years of the American Academy of Dermatology skin cancer screening program: 1985-2014. J Am Acad Dermatol 2018 Nov;79(5):884-891.e3 [FREE Full text] [doi: $10.1016 /$ j.jaad.2018.05.1242] [Medline: $\underline{\text { 30057360] }}$

11. Geller AC, Greinert R, Sinclair C, Weinstock MA, Aitken J, Boniol M, et al. A nationwide population-based skin cancer screening in Germany: proceedings of the first meeting of the International Task Force on Skin Cancer Screening and Prevention (September 24 and 25, 2009). Cancer Epidemiol 2010 Jun;34(3):355-358. [doi: 10.1016/j.canep.2010.03.006] [Medline: 20381443]

12. Trautmann F, Meier F, Seidler A, Schmitt J. Effects of the German skin cancer screening programme on melanoma incidence and indicators of disease severity. Br J Dermatol 2016 Nov;175(5):912-919. [doi: 10.1111/bjd.14758] [Medline: 27203791]

13. Kimball AB, Resneck JS. The US dermatology workforce: a specialty remains in shortage. J Am Acad Dermatol 2008 Nov;59(5):741-745. [doi: 10.1016/j.jaad.2008.06.037] [Medline: 18723242]

14. Aneja S, Aneja S, Bordeaux JS. Association of increased dermatologist density with lower melanoma mortality. Arch Dermatol 2012 Feb;148(2):174-178. [doi: 10.1001/archdermatol.2011.345] [Medline: 22351816]

15. Goulding JMR, Levine S, Blizard RA, Deroide F, Swale VJ. Dermatological surgery: a comparison of activity and outcomes in primary and secondary care. Br J Dermatol 2009 Jul;161(1):110-114. [doi: 10.1111/j.1365-2133.2009.09228.x] [Medline: 19438854]

16. Koelink CJL, Vermeulen KM, Kollen BJ, de Bock GH, Dekker JH, Jonkman MF, et al. Diagnostic accuracy and cost-effectiveness of dermoscopy in primary care: a cluster randomized clinical trial. J Eur Acad Dermatol Venereol 2014 Nov;28(11):1442-1449. [Medline: 25493316]

17. Swetter SM, Chang J, Shaub AR, Weinstock MA, Lewis ET, Asch SM. Primary Care-Based Skin Cancer Screening in a Veterans Affairs Health Care System. JAMA Dermatol 2017 Dec 01;153(8):797-801 [FREE Full text] [doi: 10.1001/jamadermatol.2017.1324] [Medline: 28593242]

18. Beecher SM, Keogh C, Healy C. Dedicated general practitioner education sessions can improve diagnostic capabilities and may have a positive effect on referral patterns for common skin lesions. Ir J Med Sci 2018 Nov;187(4):959-963. [doi: 10.1007/s11845-018-1788-z] [Medline: 29541934]

19. Ahmadi K, Prickaerts E, Smeets JGE, Joosten VHMJ, Kelleners-Smeets NWJ, Dinant GJ. Current approach of skin lesions suspected of malignancy in general practice in the Netherlands: a quantitative overview. J Eur Acad Dermatol Venereol 2018 Feb;32(2):236-241. [doi: 10.1111/jdv.14484] [Medline: 28750138]

20. van Rijsingen MCJ, Hanssen SCA, Groenewoud JMM, van der Wilt GJ, Gerritsen MP. Referrals by general practitioners for suspicious skin lesions: the urgency of training. Acta Derm Venereol 2014 Mar;94(2):138-141 [FREE Full text] [doi: 10.2340/00015555-1752] [Medline: 24352366]

21. Esteva A, Kuprel B, Novoa RA, Ko J, Swetter SM, Blau HM, et al. Dermatologist-level classification of skin cancer with deep neural networks. Nature 2017 Dec 02;542(7639):115-118. [doi: 10.1038/nature21056] [Medline: 28117445]

22. Haenssle HA, Fink C, Schneiderbauer R, Toberer F, Buhl T, Blum A, Reader study level-Ilevel-II Groups. Man against machine: diagnostic performance of a deep learning convolutional neural network for dermoscopic melanoma recognition in comparison to 58 dermatologists. Ann Oncol 2018 Aug 01;29(8):1836-1842. [doi: 10.1093/annonc/mdy166] [Medline: 29846502]

23. Udrea A, Lupu C. Real-time acquisition of quality verified non-standardized color images for skin lesions risk assessment? A preliminary study, 18th International Conference on System Theory, Control and Computing (ICSTCC), 2014. 2014 Presented at: 18th International Conference on System Theory; 2014; Sinaia, Romania. [doi: 10.1109/ICSTCC.2014.6982415]

24. Maier T, Kulichova D, Schotten K, Astrid R, Ruzicka T, Berking C, et al. Accuracy of a smartphone application using fractal image analysis of pigmented moles compared to clinical diagnosis and histological result. J Eur Acad Dermatol Venereol 2015 Apr;29(4):663-667. [doi: 10.1111/jdv.12648] [Medline: 25087492]

25. Thissen M, Udrea A, Hacking M, von Braunmuehl T, Ruzicka T. mHealth App for Risk Assessment of Pigmented and Nonpigmented Skin Lesions-A Study on Sensitivity and Specificity in Detecting Malignancy. Telemed J E Health 2017 May 31. [doi: 10.1089/tmj.2016.0259] [Medline: 28562195]

26. Isola P, Zhou JY, Zhou T, Efros A. Image-to-Image Translation with Conditional Adversarial Networks. 2017 Presented at: IEEE Conference on Computer Vision and Pattern Recognition; 2017; Honolulu, Hawai, United States p. 3.

27. Telea A. An Image Inpainting Technique Based on the Fast Marching Method. Journal of Graphics Tools 2004;9(1):25-36. [doi: 10.1080/10867651.2004]

28. Li J, Li B. Parameters Selection for Support Vector Machine Based on Particle Swarm Optimization. Intelligent Computing Theory 2014;8588:41-47. [doi: 10.1007/978-3-319-09333-8_5] 
29. Ngoo A, Finnane A, McMeniman E, Soyer H, Janda M. Fighting Melanoma with Smartphones: A Snapshot of Where We are a Decade after App Stores Opened Their Doors. Int J Med Inform 2018;118:99-112. [Medline: $\underline{30153928]}$

30. Kassianos AP, Emery JD, Murchie P, Walter FM. Smartphone applications for melanoma detection by community, patient and generalist clinician users: a review. Br J Dermatol 2015 Jun;172(6):1507-1518. [doi: 10.1111/bjd.13665] [Medline: 25600815]

31. AppAdvice. Derma Compare by Emerald Medical Applications URL: https://appadvice.com/app/derma-compare/982517772 [accessed 2019-07-02]

32. Chen R, Snorrason M, Enger S, Mostafa E, Ko J, Aoki V, et al. Validation of a Skin-Lesion Image-Matching Algorithm Based on Computer Vision Technology. Telemed J E Health 2016 Jan;22(1):45-50. [doi: 10.1089/tmj.2014.0249] [Medline: 26218353]

33. AppAdvice. Lubax - Skin lesion ID using image recognition by Lubax, Inc URL: https://appadvice.com/app/ lubax-skin-lesion-id-using-image-recognition/956423382 [accessed 2019-07-02]

34. AppBrain. mSkin Doctor Mobile Application for Skin Cancer Detection by Aleem Technologies URL: https://www. appbrain.com/app/mskin-doctor/com.maleemtaufiq.mSkinDoctor [accessed 2019-07-02]

35. AppAdvice. MySkinMap by Xyrupt Technologies, LLC URL: https://appadvice.com/app/myskinmap/1151655127 [accessed 2019-07-02]

36. AppAdvice. SkinScan by TeleSkin ApS URL: https://appadvice.com/app/skinscan/1025190936 [accessed 2019-07-02]

37. SkinVision. URL: https://www.skinvision.com/ [accessed 2019-07-02]

38. Google Play. SpotMole URL: https://play.google.com/store/apps/details?id=com.spotmole\&hl=nl [accessed 2019-07-02]

39. American Cancer Society. Signs and Symptoms of Melanoma Skin Cancer URL: https://www.cancer.org/cancer/ melanoma-skin-cancer/detection-diagnosis-staging/signs-and-symptoms.html [accessed 2019-07-02]

40. Ngoo A, Finnane A, McMeniman E, Tan J, Janda M, Soyer HP. Efficacy of smartphone applications in high-risk pigmented lesions. Australas J Dermatol 2017 Feb 27. [doi: 10.1111/ajd.12599] [Medline: 28240347]

41. Dorairaj JJ, Healy GM, McInerney A, Hussey AJ. Validation of a Melanoma Risk Assessment Smartphone Application. Dermatol Surg 2017 Feb;43(2):299-302. [doi: 10.1097/DSS.0000000000000916] [Medline: 28165352]

42. Chuchu N, Takwoingi Y, Dinnes J, Matin R, Bassett O, Moreau J, Cochrane Skin Cancer Diagnostic Test Accuracy Group. Smartphone applications for triaging adults with skin lesions that are suspicious for melanoma. Cochrane Database Syst Rev 2018 Dec 04;12:CD013192. [doi: 10.1002/14651858.CD013192] [Medline: 30521685]

43. Brinker TJ, Hekler A, Utikal JS, Grabe N, Schadendorf D, Klode J, et al. Skin Cancer Classification Using Convolutional Neural Networks: Systematic Review. J Med Internet Res 2018 Dec 17;20(10):e11936 [FREE Full text] [doi: 10.2196/11936] [Medline: 30333097]

44. Brunssen A, Waldmann A, Eisemann N, Katalinic A. Impact of skin cancer screening and secondary prevention campaigns on skin cancer incidence and mortality: A systematic review. J Am Acad Dermatol 2017;76(1):e10. [Medline: 27707591]

45. Linos E, Katz KA, Colditz G. Skin Cancer-The Importance of Prevention. JAMA Intern Med 2016;176(10):1435-1436. [Medline: 27459394]

46. Gordon L, Rowell D. Health system costs of skin cancer and cost-effectiveness of skin cancer prevention and screening: a systematic review. Eur J Cancer Prev 2015;24(2). [Medline: 25089375]

47. Makin JK, Warne CD, Dobbinson SJ, Wakefield MA, Hill DJ. Population and age-group trends in weekend sun protection and sunburn over two decades of the SunSmart programme in Melbourne, Australia. Br J Dermatol 2013 Jan;168(1):154-161. [doi: 10.1111/bjd.12082] [Medline: 23039760]

48. Porter M, Kimball A. Predictions, Surprises, and the Future of the Dermatology Workforce. JAMA Dermatol 2018;154(11):1253-1255. [Medline: $\underline{30193360]}$

49. Bashshur R, Shannon G, Tejasvi T, Kvedar J, Gates M. The Empirical Foundations of Teledermatology: A Review of the Research Evidence. Telemed J E Health 2015;21(12). [Medline: 26394022]

50. National Institute for Health and Care Excellence. 2019. Evidence Standards Framework for Digital Health Technologies, March 2019 URL: https://www.nice.org.uk/Media/Default/About/what-we-do/our-programmes/ evidence-standards-framework/digital-evidence-standards-framework.pdf [accessed 2019-07-02]

51. Zhao Y, Ni Q, Zhou R. What factors influence the mobile health service adoption? A meta-analysis and the moderating role of age. International Journal of Information Management 2018 Dec;43:342-350. [doi: 10.1016/j.ijinfomgt.2017.08.006]

52. Koelink C, Kollen B, Groenhof F, van der Meer K, van der Heide W. Skin lesions suspected of malignancy: an increasing burden on general practice. BMC Fam Pract 2014;15. [Medline: 24517098]

53. Geldsetzer P, Fawzi W. Quasi-experimental study designs series-paper 2: complementary approaches to advancing global health knowledge. J Clin Epidemiol 2017;89:12-16. [Medline: 28365307]

54. Eisemann N, Waldmann A, Garbe C, Katalinic A. Development of a microsimulation of melanoma mortality for evaluating the effectiveness of population-based skin cancer screening. Med Decis Making 2015;35(2):243-254. [Medline: 25145574]

55. Pil L, Hoorens I, Vossaert K, Kruse V, Tromme I, Speybroeck N, et al. Cost-effectiveness and Budget Effect Analysis of a Population-Based Skin Cancer Screening. JAMA Dermatol 2017 Feb 01;153(2):147-153. [doi:

10.1001/jamadermatol.2016.4518] [Medline: 28002834] 
56. Losina E, Walensky R, Geller A, Beddingfield F, Wolf L, Gilchrest B, et al. Visual screening for malignant melanoma: a cost-effectiveness analysis. Arch Dermatol 2007 Jan;143(1):21-28 [FREE Full text] [doi: 10.1001/archderm.143.1.21] [Medline: 17224538]

57. Lansdorp-Vogelaar I, Gulati R, Mariotto A, Schechter C, de Carvalho T, Knudsen A, et al. Personalizing age of cancer screening cessation based on comorbid conditions: model estimates of harms and benefits. Ann Intern Med 2014 Jul 15;161(2):104-112 [FREE Full text] [doi: 10.7326/M13-2867] [Medline: 25023249]

\section{Abbreviations}

BCC: basal cell carcinoma

CISNET: Cancer Intervention and Surveillance Modelling Network

GP: general practitioner

mHealth: mobile health

MM: malignant melanoma

RCT: randomized control trial

SCC: squamous cell carcinoma

SVM: support vector machine

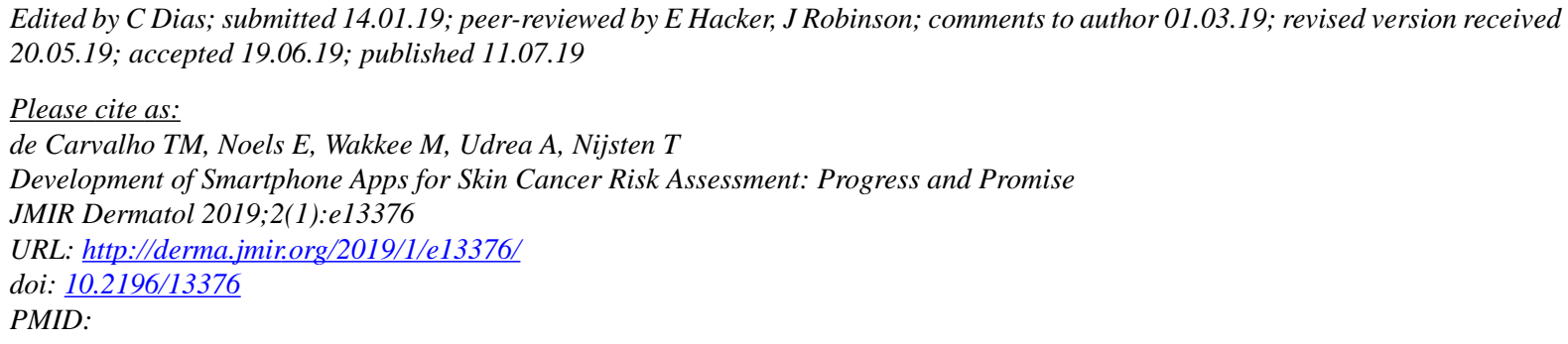

(C)Tiago M de Carvalho, Eline Noels, Marlies Wakkee, Andreea Udrea, Tamar Nijsten. Originally published in JMIR Dermatology (http://derma.jmir.org), 11.07.2019. This is an open-access article distributed under the terms of the Creative Commons Attribution License (https://creativecommons.org/licenses/by/4.0/), which permits unrestricted use, distribution, and reproduction in any medium, provided the original work, first published in JMIR Dermatology Research, is properly cited. The complete bibliographic information, a link to the original publication on http://derma.jmir.org, as well as this copyright and license information must be included. 